\title{
The importance of habitat diversity and plant species richness for hazel grouse occurrence in the mixed mountain forests of the Western Carpathians
}

\author{
Marcin Matysek $^{1,2} \cdot$ Robert Gwiazda $^{2}$ (D) Zbigniew Bonczar ${ }^{3}$
}

Received: 7 February 2020 / Revised: 1 July 2020 / Accepted: 21 July 2020 / Published online: 15 August 2020

(c) The Author(s) 2020

\begin{abstract}
Hazel grouse habitat requirements are relatively well known in coniferous forests, and less known in mixed or deciduous forests. We studied habitat differences between sites occupied by hazel grouse Tetrastes bonasia and control plots in mixed mountain forests of the Western Carpathians in 2009 and 2010. Hazel grouse presence at sites was determined in April and May. The habitat variables $(n=21)$ and the proportion of tree and shrub species $(n=22)$ were collected both in sites of hazel grouse presence and control plots within a radius of $100 \mathrm{~m}$. Greater numbers of tree species and greater proportions of deciduous trees (mainly birch Betula sp.) were found in sites where hazel grouse was present. Lower canopy cover was an important variable for hazel grouse occurrence, and sites with hazel grouse had a greater proportion of young trees ( $<40$ years). Sites were also characterized by a higher proportion of overgrown glades and dead woods in comparison with control plots. Sites occupied by hazel grouse were characterized by a greater number of tree species in the undergrowth (minimum of five species) in comparison with control plots. GLM models revealed that the most important environmental factors for hazel grouse occurrence in mixed mountain forests were open habitats (overgrown glades), good hiding opportunities (fallen trees and dead woods) and good conditions for foraging (trees cover in undergrowth). Poplar (Populus sp.) and willow (Salix sp.) were the most important tree species for hazel grouse occurrence. The presence of habitat structures and the vegetations richness provides good shelter or food for the hazel grouse. Extensive forest management should be proposed to increase the number of hazel grouse. Large areas covered by herbs and light-seeded tree species of low economical value for forestry are recommended to support hazel grouse population.
\end{abstract}

Keywords Environmental factors $\cdot$ Habitat structure $\cdot$ Mixed forests $\cdot$ Site occupancy $\cdot$ Plant species richness $\cdot$ Tetraonidae

\section{Introduction}

Preservation of various forest structures is important for the protection of endangered species (Zellweger et al. 2013; Kajtoch et al. 2012, 2016). To be able to preserve relevant

Communicated by Claus Bässle.

Zbigniew Bonczar: deceased.

Robert Gwiazda

gwiazda@iop.krakow.pl

1 Tatra National Park, Kuźnice 1, 34-500 Zakopane, Poland

2 Institute of Nature Conservation, Polish Academy of Sciences, Adama Mickiewicza 33, 31-120 Kraków, Poland

3 Faculty of Animal Science, University of Agriculture in Krakow, Mickiewicza 24/28, 30-059 Kraków, Poland structures, it is necessary to know the requirements of these species in different habitats. Forest-dwelling birds are often seriously threatened, particularly in regions where habitat transformation and fragmentation are well advanced (Kajtoch et al. 2012). Forest structure is crucial for the distribution and abundance of many bird species, including hazel grouse Tetrastes bonasia (Swenson and Angelstam 1993; Lycke et al. 2011; Storch 2013; Zhang et al. 2013; Kortmann et al. 2018) which is generally considered to be a sedentary forest-specialist (Bergmann et al. 1982; Swenson 1991a; Montadert and Leonard 2006). Hazel grouse prefers large coniferous and mixed forests, but can also inhabit fragmented, smaller forest complexes. This species depends on different habitats and food resources throughout the year and could not survive and reproduce in areas which do not sufficiently provide all resources (Chalfoun and Martin 2007; Aldridge and Boyce 2008; Kajtoch et al. 2016; Matysek 
et al. 2018). The hazel grouse forages on different plants, including trees, shrubs and herbs, as well as invertebrates during the breeding season (Cramp and Simmons 1980). This species also requires certain plant structures to survive different phenological seasons (Ludwig and Klaus 2017; Matysek et al. 2018). Greater proportion of deciduous trees and greater species richness in spring sites of this species was found in comparison with winter sites (Matysek et al. 2018). It is searching for food on the ground in summer and on shrubs and pioneer trees in winter.

Hazel grouse habitat requirements are relatively well known in boreal and mountain ecosystems covered by coniferous forests (Bergmann et al. 1996; Kämpfer-Lauenstein 1997; Åberg et al. 2003; Mathys et al. 2006; Müller et al. 2009; Schäublin and Bollman 2011; Ludwig and Klaus 2017), and less known in mixed or deciduous forests (Wiesner et al. 1977; Rhim 2006; Kajtoch et al. 2012; Matysek et al. 2018, 2019). Habitat preferences differ in detail according to diversity of available sites. Forest structure and composition in Fennoscandia and in the Alps differ strongly from those in the Carpathian foothills where mixed forests have been transformed with numerous overgrowing glades and a high degree of fragmentation.

Hazel grouse is still quite abundant in some areas of Europe (Hagemeijer and Blair 1997; BirdLife International 2004); however, while populations are stable in north, they are decreasing in most Western and Central European countries (Swenson and Danielson 1991; Storch 2000). The species is relatively widely distributed in the Polish Carpathians (predominantly in the mountains) but is less prevalent in the foothills (Kajtoch et al. 2011; Matysek 2016).

Hazel grouse habitat requirements have already been studied in the Carpathians, but only for the lowest (covered by mixed forests) and the highest altitudes (dominated by spruce forests). They were not studied in another forest type at medium altitudes (mainly covered by mixed forests with beech, spruce and fir). The aim of this study was to quantify the habitat requirements of hazel grouse in the mixed forests of the Carpathian Mountains at the medium altitudes. Understanding of habitat variables which are necessary for the occurrence of this species is important in its protection and reintroduction.

\section{Study area}

The study was carried out in the eastern part of the Makowski Beskid Mountains (Western Carpathians, southern Poland) $\left(49.48^{\circ} \mathrm{N}, 19.51^{\circ} \mathrm{E}\right)$. The altitude of the study area is between 450 and 857 meters a.s.l. This area comprises moderately high hills covered by forests and agricultural areas (fields and meadows). Mixed forests with coniferous trees are located mostly on the hilltops and in valleys.
Forests with varying proportions of spruce Picea abies, fir Abies alba, pine Pinus sylvestris, beech Fagus sylvatica, birch Betula sp. and other tree species cover more than 50\% of the study area. The forested area consists of a mosaic of woodland patches with overgrown glades. Most forests belong to private owners, with the remainder belonging to the Polish Forestry Services. State forests consist predominantly of beech, fir and spruce, while private forests mainly comprise spruce and fir. The oldest forests contain dying trees and dead woods. These forests occupy ca. $20 \%$ of the total forest area. Forest stands tend to be younger in private forests. Juvenile forest communities comprise different species (birch, poplar Populus sp., willow Salix sp., sycamore Acer pseudoplatanus). Pastures, meadows and fields are in many places (Ostafin 2009). Most forest stands are extensively managed (with selective cutting of trees). Villages are located mostly along valleys. Such diversity in forest characteristics provides a large area of habitat heterogeneity.

\section{Methods}

\section{Hazel grouse monitoring}

Places considered as potential habitats for the hazel grouse were selected based on the analysis of satellite images and topographic maps. The selected places were visited at least twice in each season 2009 and 2010 to find hazel grouse sites. MP3 speakers playing hazel grouse male territorial calls from playback were used to detect potential occurrence of individuals in spring (April and May). The presence of hazel grouse was investigated every $150 \mathrm{~m}$ walk along a transect. After 3 min of listening, the observer moved on to the next sampling point (Bonczar 2009). The surveys were performed only in good weather conditions and mainly during mornings and evenings, as Swenson (1991b) found a lower response frequency during midday. The recorded sites were mapped in the field. Additionally, traces of existence such as tracks, feathers, sand bathing places or droppings were noted. In places where such traces were found, hazel grouse was detected playing its calls from playback. We found 19 sites occupied by hazel grouse (where birds answered to imitations of its calls). Control plots were chosen randomly in places where no hazel grouse occurrence was found.

\section{Environmental data}

A total of 43 environmental variables ( 21 of habitat factors and 22 of species composition) were collected in 19 hazel grouse sites and 28 control plots in spring (Table 1). Each studied site and control plot was a circle with a radius of ca. $100 \mathrm{~m}$. Habitat factors were determined by biotic and abiotic variables in the circles (Table 1). Trees and shrubs 
Table 1 Environmental variables in sites of Hazel Grouse presence and control sites within $100 \mathrm{~m}$ radius used in analysis

\begin{tabular}{|c|c|c|}
\hline Variable & Description & Code \\
\hline \multicolumn{3}{|l|}{ Habitat factors } \\
\hline Deciduous tree proportion & Proportion of deciduous tree species & Decid \\
\hline Coniferous tree proportion & Proportion of coniferous tree species & Conif \\
\hline Stand age $<40$ years old & Proportion of tree of this age & Tree $<40$ \\
\hline Stand age $40-80$ years old & Proportion of tree of this age & Tree $40-80$ \\
\hline Stand age $80-120$ years old & Proportion of tree of this age & Tree $80-120$ \\
\hline Stand age $>120$ years old & Proportion of tree of this age & Tree $>120$ \\
\hline Richness of trees in canopy & Number of tree species in canopy & Tree rich \\
\hline Tree cover in canopy (\%) & Proportion of stand forest cover & Tree cover \\
\hline Richness of trees in understory & Number of tree species in understory & Bush rich \\
\hline Tree cover in understory $(\%)$ & Proportion of tree cover in understory & Bush cover \\
\hline Richness of trees in undergrowth & Number of tree species in undergrowth & Un rich \\
\hline Tree cover in undergrowth $(\%)$ & Proportion of tree cover in undergrowth & Un cover \\
\hline Grass and herbs richness & $\begin{array}{l}\text { Categorical: }<10 \text { species, } 10-20 \text { species, }>20 \\
\text { species) }\end{array}$ & Herbs rich \\
\hline Grass and herbs cover & Categorical: $0-25 \%, 25-50 \%,>50 \%$ & Herbs cover \\
\hline Glades & Presence/absence & Glades \\
\hline Clearcuttings & Presence/absence & ClearFell \\
\hline Fallen trees & Presence/absence & FallTree \\
\hline Dead woods & Presence/absence & DeadW \\
\hline Ravines & Presence/absence & Ravin \\
\hline Streams & Presence/absence & Stream \\
\hline Unpaved roads & Presence/absence & Unroad \\
\hline \multicolumn{3}{|l|}{ Species composition } \\
\hline Spruce Picea albies & Proportion of this species & Spr \\
\hline Pine Pinus sylvestris & Proportion of this species & Pine \\
\hline Fir Abies alba & Proportion of this species & Fir \\
\hline Larch Larix deciduas & Proportion of this species & Larch \\
\hline Oak Querqus sp. & Proportion of this species & Oak \\
\hline Beech Fagus sylvaticus & Proportion of this species & Beech \\
\hline Birch etula pendula & Proportion of this species & Birch \\
\hline Hornbeam Carpinus betulus & Proportion of this species & Hor \\
\hline Ash Fraxinus excelsior & Proportion of this species & Ash \\
\hline Sycamore Acer pseudoplatanus & Proportion of this species & Syc \\
\hline Linden Tilia sp. & Proportion of this species & Lin \\
\hline Alder Alnus sp. & Proportion of this species & Ald \\
\hline Poplar Populus sp. & Proportion of this species & Pop \\
\hline Hazel Corylus avellana & Proportion of this species & Haz \\
\hline Willow Salix sp. & Proportion of this species & Wil \\
\hline Elm Ulmus sp. & Proportion of this species & Elm \\
\hline Rowan Sorbus aucuparia & Proportion of this species & Row \\
\hline Viburnum Viburnum sp. & Proportion of this species & Vib \\
\hline Hawthorn Crataegus sp. & Proportion of this species & Haw \\
\hline Wild Cherry Prunus avium & Proportion of this species & Wcherry \\
\hline Bird Cherry Prunus padus & Proportion of this species & Bcherry \\
\hline Beige Sambucus sp. & Proportion of this species & Beige \\
\hline
\end{tabular}

were considered to be an element of undergrowth, understory and canopy depending on the height (up to $0.5 \mathrm{~m}$, 0.5-5 m, more than $5 \mathrm{~m}$, respectively). Also the species composition was determined by the proportion of tree and shrub species in the studied site in a circle with a radius of ca. $100 \mathrm{~m}$ (Table 1). 


\section{Statistical analyses}

Statistical differences of habitat factors between sites where hazel grouse was present and control plots were compared using the Mann-Whitney $U$ test. A generalized linear model (GLM) with a binomial distribution was used to assess the importance of environmental variables at sites where hazel grouse was present. To build a multivariate model, it was necessary to reduce the number of variables. 'Deciduous and coniferous tree proportion' was not included in the multivariate model of the habitat factors because proportion of tree and shrub species was analyzed in the model of species composition. Principal Component Analysis was used to check collinearity among the environmental variables (Freckleton 2011). Correlated factors were classified to one group to reduce the number of factors for inclusion in the GLM model. 'Ravines' and 'Streams' were joined as one variable $(r=0.75, p<0.001)$. This variable explained $53.1 \%$ of the variance (component 1). 'Stand age' was not included to the multivariate model of the habitat factors because other factors were related to the stand age. We found correlations: between trees $<40$ years and richness of trees in undergrowth and richness of trees in understory ( $r=0.65, p<0.001$ and $r=0.62, p<0.001$, respectively), between trees 40-80 years and tree cover in undergrowth $(r=0.60, p<0.001)$, between trees $>120$ years and tree cover in undergrowth $(r=0.52, p<0.001)$, between trees $80-120$ years and slope $(r=0.57, p<0.001)$. 'Fallen trees' and 'Dead woods' were joined as one variable because they are ecologically related to each other $(r=0.53, \mathrm{p}<0.001)$. This variable explained $77.2 \%$ of the variance (component 1). Only tree species which share a minimum of $5 \%$ in the studied places were taken to multivariate analysis of the species composition. Linear regression models were used to test the importance of two groups of factors-habitat factors and species composition in forest-for hazel grouse occurrence. Akaike's information criterion (AIC) was used for best model selection (Burnham and Anderson 2004). The resulting models were subsequently ranked in order of increasing AIC; the model with the lowest AIC score and highest weight $(w)$ can be viewed as the most parsimonious as it explains most of the variance with the smallest number of parameters. Following Burnham and Anderson (2004), models with $\Delta$ AIC $<2$ compared to the model with the lowest AIC were assumed to have high strength of evidence. To determine the significance of particular variables, AIC weights (AIC $w$ ) for models containing given variables were used to assess the importance of each independent variable (Burnham and Anderson 2004). The predictor with the highest AIC $w$ was considered to be the most important. Univariate logistic regression modeling was adopted to build curves showing the relationship between number of tree species and hazel grouse presence. A multimodel inference, made by summing AIC weights for models containing given variables, was used to assess the real importance of each independent variable. We used STATISTICA version 10 for the statistical analyses (StatSoft Inc 2014).

\section{Results}

We found differences between sites where hazel grouse was present and control plots in the study area (Table 2). The presence of overgrown glades was ninefold higher which was recorded in sites occupied by hazel grouse than in control plots. Higher proportion of dead woods (2.1-fold higher) was found in sites occupied by hazel grouse compared to control plots. Sites where hazel grouse was present were characterized by greater numbers of tree species and deciduous trees compared to control plots. The abundance of poplar, alder Alnus sp., willow, birch, wild cherry Prunus avium, bird cherry Prunus padus and hazel Corylus sp. was statistically greater in sites where hazel grouse was present compared to control plots (17.6-fold higher, 14.6-fold higher, 9.4-fold higher, 8.1-fold higher, 12.0-fold higher, 6.4-fold higher, 5.1-fold higher, respectively) (Table 2). Tree species richness and their undergrowth and understory cover were higher in sites where hazel grouse was present than in control plots. Sites occupied by hazel grouse also comprised a greater proportion of young trees aged $<40$ years (share of these trees was 2.5 -fold higher than in control plots). We identified a greater mean number of tree species in the undergrowth in sites occupied by hazel grouse (5-22 species) in comparison with control plots ( $2-18$ species) $(Z=4.216, p<0.001$, $n=47)$. Contrary, the control plots were characterized by a higher proportion of coniferous trees and canopy cover. The number of tree species in the undergrowth and understory had a significant impact on the probability of hazel grouse occurrence (Fig. 1a, b). Five tree species in the undergrowth were the minimum at the sites occupied by hazel grouse.

The best model explaining hazel grouse presence included the tree cover in the undergrowth, and the occurrence of glades, fallen trees and dead woods (Table 3). GLM analysis of species composition in the forest indicated that models that included poplar and willow best explained hazel grouse presence (Table 3 ). The most important environmental factors for hazel grouse occurrence were tree cover in the undergrowth $\left(\sum\right.$ AIC $\left.w=0.78\right)$, glades $\left(\sum\right.$ AIC $\left.w=0.62\right)$ and fallen trees and dead woods $\left(\sum \operatorname{AIC} w=0.50\right)$. The proportion of poplar $\left(\sum\right.$ AIC $\left.w=0.80\right)$, willow $\left(\sum\right.$ AIC $w=0.80)$ and spruce $\left(\sum\right.$ AIC $\left.w=0.69\right)$ had the greatest importance of the forest composition in predicting hazel grouse presence at sites. 
Table 2 Basic statistics describing habitat factors and forest structure in the sites of Hazel Grouse presence and control sites

\begin{tabular}{|c|c|c|c|c|c|c|c|}
\hline \multirow[t]{2}{*}{ Variable } & \multicolumn{2}{|l|}{ Sites } & \multicolumn{2}{|c|}{ Control } & \multirow[t]{2}{*}{$Z$} & \multirow[t]{2}{*}{$p$} & \multirow[t]{2}{*}{$n$} \\
\hline & Mean & Min-Max & Mean & Min-Max & & & \\
\hline \multicolumn{8}{|l|}{ Habitat factors } \\
\hline Deciduous tree proportion & 61.5 & $0-100$ & 32.4 & $0-100$ & 3.924 & $<0.001$ & 47 \\
\hline Coniferous tree proportion & 38.5 & $0-100$ & 67.6 & $0-100$ & -3.924 & $<0.001$ & 47 \\
\hline Stand age $<40$ years old & 45.5 & $0-100$ & 18.4 & $0-100$ & 2.699 & 0.007 & 47 \\
\hline Stand age $40-80$ years old & 34.2 & $0-100$ & 42.7 & $0-100$ & -0.563 & 0.57 & 47 \\
\hline Stand age $80-120$ years old & 12.1 & $0-40$ & 27.0 & $0-100$ & -0.629 & 0.53 & 47 \\
\hline Stand age $>120$ years old & 8.2 & $0-50$ & 12.3 & $0-90$ & -0.269 & 0.79 & 47 \\
\hline Richness of trees in canopy & 5.6 & 1-10 & 3.9 & 1-11 & 1.994 & 0.046 & 47 \\
\hline Tree cover in canopy (\%) & 41.3 & $5-80$ & 62.1 & $5-100$ & -2.623 & 0.009 & 47 \\
\hline Richness of trees in understory & 12.4 & 3-22 & 4.7 & $1-15$ & 4.682 & $<0.001$ & 47 \\
\hline Tree cover in understory (\%) & 52.6 & 25-80 & 34.3 & $5-100$ & 2.807 & 0.005 & 47 \\
\hline Richness of trees in undergrowth & 13.4 & $5-22$ & 6.8 & 2-18 & 4.216 & $<0.001$ & 47 \\
\hline Tree cover in undergrowth $(\%)$ & 40.8 & 15-80 & 21.1 & $5-70$ & 3.772 & $<0.001$ & 47 \\
\hline Grass and herbs richness & 2.0 & 1-3 & 1.0 & 1-2 & 3.794 & $<0.001$ & 47 \\
\hline Grass and herbs cover & 2.3 & $1-3$ & 1.2 & $1-3$ & 3.794 & $<0.001$ & 47 \\
\hline Glades & 0.6 & $0-1$ & 0.1 & 0-1 & 3.219 & 0.001 & 47 \\
\hline Clearcuttings & 0.4 & $0-1$ & 0.1 & $0-1$ & 0.821 & 0.41 & 47 \\
\hline Fallen trees & 0.6 & $0-1$ & 0.4 & $0-1$ & 1.572 & 0.12 & 47 \\
\hline Dead woods & 0.6 & 0-1 & 0.3 & 0-1 & 2.081 & 0.04 & 47 \\
\hline Ravines & 0.4 & $0-1$ & 0.2 & $0-1$ & 0.975 & 0.33 & 47 \\
\hline Streams & 0.4 & $0-1$ & 0.2 & $0-1$ & 1.181 & 0.24 & 47 \\
\hline Unpaved roads & 0.8 & $0-1$ & 0.8 & $0-1$ & 0.184 & 0.85 & 47 \\
\hline \multicolumn{8}{|l|}{ Species composition } \\
\hline Spruce Picea albies & 23.6 & $5-70$ & 43.0 & $5-100$ & -1.539 & 0.12 & 47 \\
\hline Pine Pinus sylvestris & 1.7 & $0-8$ & 0.5 & $0-7$ & 2.330 & 0.02 & 47 \\
\hline Fir Abies alba & 18.9 & $2-67$ & 36.8 & 0-90 & -2.309 & 0.02 & 47 \\
\hline Larch Larix deciduas & 0.8 & $0-8$ & 0.3 & $0-6$ & 1.420 & 0.16 & 47 \\
\hline Oak Querqus sp. & 0.3 & $0-2$ & 0 & & 0.890 & 0.36 & 47 \\
\hline Beech Fagus sylvaticus & 7.4 & $0-23$ & 14.8 & 0-99 & -0.282 & 0.78 & 47 \\
\hline Birch Betula pendula & 25.8 & $0-67$ & 3.2 & 0-38 & 24.715 & $<0.001$ & 47 \\
\hline Hornbeam Carpinus betulus & 0.3 & $0-2$ & 0 & & 0.890 & 0.36 & 47 \\
\hline Ash Fraxinus excelsior & 0.5 & $0-3$ & 0.2 & $0-5$ & 1.327 & 0.18 & 47 \\
\hline Sycamore Acer pseudoplatanus & 3.6 & $0-12$ & 2.1 & $1-15$ & 0.790 & 0.43 & 47 \\
\hline Linden Tilia sp. & 0.2 & $0-1$ & 0 & & 0.890 & 0.36 & 47 \\
\hline Alder Alnus sp. & 2.0 & 0-12 & 0.1 & 0-2 & 2.959 & 0.003 & 47 \\
\hline Poplar Populus sp. & 3.7 & 0-10 & 0.2 & $\mathbf{0}-\mathbf{3}$ & 4.481 & $<0.001$ & 47 \\
\hline Hazel Corylus avellana & 1.7 & $0-5$ & 0.3 & $\mathbf{0}-\mathbf{3}$ & 3.388 & $<0.001$ & 47 \\
\hline Willow Salix sp. & 4.7 & 0-10 & 0.5 & 0-4 & 4.781 & $<0.001$ & 47 \\
\hline Elm Ulmus sp. & 0.1 & $0-1$ & 0 & & 0.293 & 0.77 & 47 \\
\hline Rowan Sorbus aucuparia & 1.9 & $0-5$ & 0.5 & $0-2$ & 1.744 & 0.08 & 47 \\
\hline Viburnum Viburnum sp. & 0.2 & $0-1$ & 0 & & 1.203 & 0.23 & 47 \\
\hline Hawthorn Crataegus sp. & 0.4 & $0-2$ & 0 & & 1.203 & 0.23 & 47 \\
\hline Wild Cherry Prunus avium & 0.7 & 0-2 & 0.1 & 0-1 & 2.504 & 0.01 & 47 \\
\hline Bird Cherry Prunus padus & 1.3 & $0-4$ & 0.1 & 0-1 & 3.664 & $<0.001$ & 47 \\
\hline Beige Sambucus sp. & 0.4 & $0-2$ & 0 & & 1.507 & 0.13 & 47 \\
\hline
\end{tabular}

Significant differences (Mann-Whitney test) between plots were given in bold 

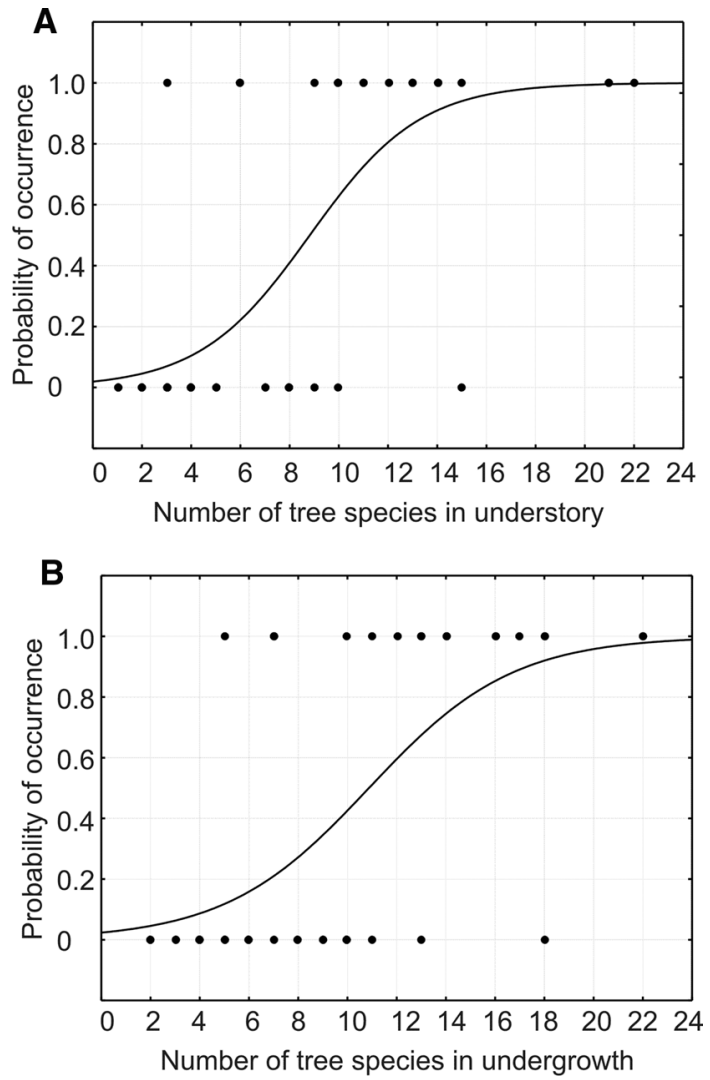

Fig. 1 Logistic regression of the probability of Hazel Grouse occurrence: a richness of trees (number of tree species) in understory, $\mathbf{b}$ richness of trees (number of tree species) in undergrowth

\section{Discussion}

Our study showed that sites occupied by hazel grouse were characterized by lower tree cover in the canopy, meaning more light could reach the forest floor and allow the development of the undergrowth and understory. Kortmann et al. (2018) showed that decreasing canopy cover increased the probability of hazel grouse presence in the Bavarian Forest (SE Germany). Moreover, we found the presence of open areas as overgrown glades was an important factor for hazel grouse occurrence in mixed mountain forests, similar as in high-mountain spruce forests (Matysek et al. 2019). Adra et al. (2013) showed that small forest openings are essential for this species in the French Alps. Hazel grouse occupies the early seral stages of forests. Kajtoch et al. (2012) determined the most important factors in the Carpathian Foothills (southern Poland) were the presence of clearings and pioneer trees. Similarly, we found a greater proportion of young trees $(<40$ years old $)$ in sites of hazel grouse presence. Juvenile tree stages are often accompanied by some pioneer species, and shrubs. Pioneer vegetation in open areas after clearcutting can increase habitat differentiation, provide good shelter and food for hazel grouse (Kajtoch et al. 2012; Matysek et al. 2018). Similar Wiesner et al. (1977) demonstrated the importance of the shrub layer of mixed woodland, particularly in earlier successional stages, for hazel grouse occurrence (east Poland). Conversely, in boreal forest (south central Sweden), hazel grouse occurred in middle-aged (20-69 years) or old ( $>90$ years) stands, but with a greater proportion of deciduous trees and a rich field layer (Åberg et al. 2003). Hazel grouse prefers areas with a better-developed understory.
Table 3 Sets of candidate GLM models (selected 5 the best models) explaining the important factors in sites of Hazel Grouse presence and control plots in the mixed mountain forests

\begin{tabular}{|c|c|c|c|c|}
\hline Models & $k$ & AIC & $\Delta$ & $w$ \\
\hline \multicolumn{5}{|l|}{ Habitat factors } \\
\hline \multicolumn{5}{|l|}{ Best models } \\
\hline Un cover + Glades + FallTreeDeadW & 4 & 63.950 & 0.000 & 0.020 \\
\hline Un cover + Herbs cover + Glades + FallTreeDeadW & 6 & 64.153 & 0.204 & 0.018 \\
\hline Un cover + Bush rich + Glades & 3 & 64.523 & 0.573 & 0.015 \\
\hline Un cover + Bush rich + Glades + FallTreeDeadW & 5 & 64.726 & 0.776 & 0.013 \\
\hline Un cover + Glades & 2 & 64.780 & 0.831 & 0.013 \\
\hline \multicolumn{5}{|l|}{ Species composition } \\
\hline \multicolumn{5}{|l|}{ Best models } \\
\hline Pop + Wil & 2 & 32.151 & 0.000 & 0.023 \\
\hline Pop +Wil + Spr & 3 & 32.491 & 0.341 & 0.019 \\
\hline Pop + Wil + Pine & 3 & 32.910 & 0.759 & 0.016 \\
\hline Beech + Birch + Pop + Wil + Fir + Spr & 6 & 33.103 & 0.952 & 0.014 \\
\hline Beech + Pop + Wil + Spr & 4 & 33.381 & 1.230 & 0.012 \\
\hline
\end{tabular}

Akaike's information criterion (AIC), difference between the given model and the most parsimonious model $(\Delta)$ and Akaike weight $(w)$ are reported for each model. Group of factors were joined "_.. Used codes were given in Table 1 
We did not find hazel grouse in sites that had lower than five tree species in the undergrowth, and it can be a limit of hazel grouse occurrence in the mixed, mountain forests. In our study, tree cover in the undergrowth and understory and the cover of grass and herbs were greater in sites of the mixed mountain forests where hazel grouse was present. The diversity of vegetation show the importance of glades or other open areas in forest for occurring of hazel grouse. Areas rich in grass and herbs on the forest floor are important for hazel grouse because they provide a rich food base in the undergrowth as well as better possibilities to hide. In the Bohemian Forest (Czech Republic), sites with hazel grouse were positively influenced by higher proportions of herbs but negatively influenced by a higher proportion of grass cover (Ludwig and Klaus 2017; Klaus and Ludwig 2018). Mixed forests with rich understory and undergrowth layers deliver appropriate food supply and living conditions for this species. This species often feeds on the ground; therefore, the greater species richness in the undergrowth is an important component of its occurrence. Mathys et al. (2006) showed that stand structure and shrub and herb coverage were essential habitat variables for hazel grouse occurrence in the Jura mountains (Switzerland). However, Vauhkonen and Imponen (2016) showed the understory, shrub and herb layers were not suitable for habitat mapping of Hazel Grouse in boreal forest in Finland.

Hazel grouse prefers richly structured forest stands with a canopy of tall trees, such as spruce and fir, but that also comprise smaller species such as alder, birch or willow in clearings (Cramp and Simmons 1980; Swenson 1991a; Bergmann et al. 1996; Swenson 2006). GLM models revealed the importance of poplar and willow at sites occupied by hazel grouse in the mixed mountain forests. Seeds and buds of deciduous species are food for hazel grouse, and indeed, higher species richness and proportion of trees giving seeds or fruit in our study were found to be important factors for the hazel grouse occurrence. Moreover, in our study, hazel grouse occurrence was associated with a greater number of tree species in all layers (canopy, understory and undergrowth), and a greater proportion of deciduous trees (mainly birch). Hazel grouse occupied habitats rich in alder (79\%), followed by birch and/or hazel $(64 \%)$ in the Bohemian Forest (Šumava, Czech Republic) (Klaus and Ludwig 2018). Schäublin and Bollman (2011) showed that hazel grouse preferred forests with high proportions of alder and a diverse mosaic of canopy and stand structure in the Swiss Alps. The importance of alder for hazel grouse occurrence in the Fennoscandian boreal forest was confirmed by Swenson (2006). We also found a greater proportion of alder in the sites occupied by hazel grouse presence. The species preferred sites with a dense understory of rowan Sorbus sp., willow, beech and spruce in the upper part (1100-1600 m a.s.l.) of the Jura mountains (Switzerland) (Sachot et al. 2003). However, we did not find a greater proportion of rowan in the sites occupied by hazel grouse in the mixed mountain forests. The species requires certain plant species in their diet to survive different phenological seasons (Ludwig and Klaus 2017; Matysek et al. 2018). Generally, hazel grouse consumes flowers and leaves of birch, alder, aspen, willow, linden Tilia sp., shoots of herbs and small bushes in spring (Glutz von Blotzheim et al. 1973). Matysek et al. (2018) showed that habitat differentiation plays an important role for hazel grouse in the Carpathian Mountains (southern Poland).

Our study revealed that hazel grouse sites were characterized by a greater presence of fallen trees and dead woods. Similar showed that these structures was positively associated with hazel grouse site occupancy in the Bohemian Forest (Šumava, Czech Republic) (Ludwig and Klaus 2017; Klaus and Ludwig 2018). The environmental structures give the possibility to avoid predators and provides sites for nests (Montadert and Leonard 2004; Seibold et al. 2013).

Heterogeneity of the environment has decreased in most of the Carpathian forests (Kajtoch et al. 2016). Areas where hazel grouse was present were characterized by higher habitat diversity (Matysek et al. 2018). Low habitat heterogeneity and a simplified forest structure decrease the availability of shelter and food for hazel grouse (Matysek et al. 2018). High species richness, including herbs and trees giving seeds or fruit, seems to be important in determining the presence of hazel grouse. Therefore, the presence of such species as willow, birch, alder, hazel and poplar is important for the protection of the hazel grouse. Extensive forest management in forests should be proposed to increase the number of hazel grouse. Natural regeneration of forest after felling should be used more often. For improving the habitat of this species, we recommend to leave areas of vegetation richness. Lightseeded tree species, and admixed tree or bush species of low economical value for forestry, but whose seeds or fruits constitute its food are important for occurrence of hazel grouse. This study broadens our knowledge and allows better understanding the habitat requirements and occurrence of the hazel grouse in another type of forest than in Alps and Scandinavia (dominated by coniferous forests).

Authors' contribution All authors contributed equally to the work.

Funding This work was partly supported by the Institute of Nature Conservation, Polish Academy of Sciences.

Availability of data and material No data are available. All data generated or analyzed during this study are included in this published article

Code availability Not applicable. 


\section{Compliance with ethical standards}

Conflict of interest The authors declare that they have no conflict of interest.

Consent to participate Authors made substantial contributions to the conception of the work; the acquisition, analysis and interpretation of data.

Consent for publication Authors approved the version to be published and agree to be accountable for all aspects of the work.

Open Access This article is licensed under a Creative Commons Attribution 4.0 International License, which permits use, sharing, adaptation, distribution and reproduction in any medium or format, as long as you give appropriate credit to the original author(s) and the source, provide a link to the Creative Commons licence, and indicate if changes were made. The images or other third party material in this article are included in the article's Creative Commons licence, unless indicated otherwise in a credit line to the material. If material is not included in the article's Creative Commons licence and your intended use is not permitted by statutory regulation or exceeds the permitted use, you will need to obtain permission directly from the copyright holder. To view a copy of this licence, visit http://creativecommons.org/licenses/by/4.0/.

\section{References}

Åberg J, Swenson JE, Angelstam P (2003) The habitat requirements of hazel grouse (Bonasa bonasia) in managed boreal forest and applicability of forest stand descriptions as a tool to identify suitable patches. Forest Ecol Manag 175:437-444

Adra W, Delcros P, Luque S (2013) Landscape structure indicators as a key feature in habitat selection: an operational approach to conservation planning. J Biodivers Endanger Species 1:107. https ://doi.org/10.4172/2332-2543.1000107

Aldridge CL, Boyce MS (2008) Accounting for fitness: combining survival and selection when assessing wildlife-habitat relationships. Isr J Ecol Evol 53:389-419

Bergmann HH, Klaus S, Müller F, Wiesner J (1982) Das Haselhuhn Bonasa bonasia Wittenberg. [The Hazel Grouse] Lutherstadt: Die NeueBrehm-Bücherei (in German)

Bergmann HH, Klaus S, Müller F, Scherzinger W, Swenson JE, Wiesner J (1996) Die Haselhühner, Bonasa bonasia und B. Sewerzowi. Die Neue Brehm-Bücherei, Westrap Wissenschaften, Magdeburg (in German)

Birdlife International (2004) Birds in Europe: population estimates, trends and conservation status. Birdlife International, Cambridge

Bonczar Z (2009) Hazel Grouse Bonasa bonasia. In: Chylarecki P, Sikora A, Cenian Z (eds) Monitoring of breeding birds. Methodological guide concerning species protected by Birds Directive. Biblioteka Monitoringu Środowiska, Warszawa, pp 287-291 (in Polish)

Burnham KP, Anderson DR (2004) Multimodel inference. Understanding AIC and BIC in model selection. Sociol Method Res 33:261-304

Chalfoun AD, Martin TE (2007) Assessments of habitat preferences and quality depend on spatial scale and metrics of fitness. J Appl Ecol 44:983-992

Cramp S, Simmons KEL (1980) The birds of the Western Palearctic. Handbook of the Birds of Europe, the Middle East and North Africa. 2. Oxford University Press, Oxford
Freckleton RP (2011) Dealing with collinearity in behavioural and ecological data: model averaging and the problems of measurement error. Behav Ecol Sociobiol 65:91-101

Glutz von Blotzheim UM, Bauer KM, Bezzel E (1973) Handbuch der Vogel Mitteleuropeas. 5. Frankfurt am Main

Hagemeijer EJM, Blair MJ (eds) (1997) The EBCC Atlas of European Breeding Birds: their distribution and abundance. T and AD Poyser, London

Kajtoch $Ł$, Matysek M, Skucha P (2011) Forest grouses Tetraoninae of Beskid Wyspowy and Beskid Makowski Mountains and adjacent foothills. Chrońmy Przyr Ojcz. 67(1):27-38 (in Polish with English summary)

Kajtoch Ł, Żmihorski M, Bonczar Z (2012) Hazel Grouse occurrence in fragmented forests: habitat quantity and configuration is more important than quality. Eur J Forest Res 131:1783-1795

Kajtoch $Ł$, Wilk T, Bobrek R, Matysek M (2016) The importance of forests along submontane stream valleys for bird conservation: the Carpathian example. Bird Conserv Int 26(3):350-365

Kämpfer-Lauenstein A (1997) Habitat selection of hazel grouse Bonasa bonasia and natural dynamics in different central European woodland associations. Wildl Biol 3:289

Klaus S, Ludwig T (2018) Ökologie und Schutz des Haselhuhns Tetrastes bonasia im Böhmerwald (Šumava, Tschechien). Charadrius 54. Heft 2-3:119-128 (in German with English summary)

Kortmann M, Heurich M, Latifi H, Rösner S, Seidl R, Müller J, Thorn S (2018) Forest structure following natural disturbances and early succession provides habitat for two avian flagship species, capercaillie (Tetrao urogallus) and hazel grouse (Tetrastes bonasia). Biol Conserv 226:81-91

Ludwig T, Klaus S (2017) Habitat selection in the post-breeding period by Hazel Grouse Tetrastes bonasia in the Bohemian Forest. J Ornithol 158:101-112. https://doi.org/10.1007/s10336-016-1365-Z

Lycke A, Imbeau L, Drapeau P (2011) Effects of commercial thinning on site occupancy and habitat use by spruce grouse in boreal Quebec. Can J For Res 41:501-508. https://doi.org/10.1139/X10-226

Mathys L, Zimmermann NE, Zbinden N, Suter W (2006) Identifying habitat suitability for hazel grouse Bonasa bonasia at the landscape scale. Wildl Biol 12:357-366

Matysek M (2016) Hazel Grouse (Tetrastes bonasia). In: Wilk T, Bobrek R, Pępkowska-Król A, Neubauer G, Kosicki JZ (eds) The birds of the Polish Carpathian-status, threats, conservation. OTOP, Marki, pp 112-120 (in Polish with English summary)

Matysek M, Gwiazda R, Bonczar Z (2018) Seasonal changes of the Hazel Grouse Tetrastes bonasia habitat requirements in managed mountain forests (Western Carpathians). J Ornithol 159(1):115-127

Matysek M, Kajtoch Ł, Gwiazda R, Binkiewicz B, Szewczyk G (2019) Could gaps and diverse topography compensate for habitat deficiency by the forest-dwelling bird Hazel Grouse (Tetrastes bonasia)? Avian Biol Res 12(1):59-66

Montadert M, Leonard P (2004) First results of a hazel grouse population study in the south-eastern French Alps. Grouse News 28:15-20

Montadert M, Leonard P (2006) Post-juvenile dispersal of Hazel Grouse Bonasa bonasia in an expanding population of the southeastern French Alps. Ibis 148:1-13

Müller D, Schröder B, Müller J (2009) Modelling habitat selection of the cryptic Hazel Grouse Bonasa bonasia in a montane forest. J Ornithol 150(4):717-732

Ostafin K (2009) Zmiany granic rolno-leśnej w środkowej części Beskidu Średniego od połowy XIX wieku do 2005 roku. Wydawnictwo Uniwersytetu Jagiellońskiego. ISBN 978-83-2332712-7 (in Polish)

Rhim S-J (2006) Home range and habitat selection of hazel grouse Bonasa bonasia in a temperate forest of South Korea. For Ecol Manag 226(1-3):22-25 
Sachot S, Perrin N, Neet C (2003) Winter habitat selection by two sympatric forest grouse in western Switzerland: implications for conservation. Biol Conserv 112:373-382

Schäublin S, Bollman K (2011) Winter habitat selection and conservation of Hazel Grouse (Bonasa bonasia) in mountain forests. J Ornithol 152:179-192

Seibold S, Hempel A, Piehl S, Bässler C, Brandl R, Rösner S, Müller J (2013) Forest vegetetion structure has mor influence on predation risk of artificial ground nests than human activities. Basic Appl Ecol 14(8):687-693

StatSoft Inc (2014) STATISTICA (data analysis software system), version 12. http://www.statsoft.pl. Accessed 7 Jan 2016

Storch I (2000) Conservation status and threats to grouse worldwide: an overview. Wildl Biol 6:195-204

Storch I (2013) Human disturbance of grouse-why and when? Wildlife Biol 19:390-403

Swenson JE (1991a) Social organization of Hazel Grouse and ecological factors influencing it. Ph.D. thesis. University of Alberta, Edmonton

Swenson JE (1991b) Evaluation of the density index for territorial male from Hazel Grouse Bonasa bonasia in spring and autumn. Ornis Fenn 68:57-65

Swenson JE (2006) The importance of alder to Hazel Grouse in Fennoscandian boreal forest: evidence from four levels of scale. Ecography $16(1): 37-46$
Swenson JE, Angelstam P (1993) Habitat separation by sympatric forest grouse in Fennoscandia in relation to boreal forest succession. Can J Zool 71(7):1303-1310

Swenson JE, Danielson J (1991) Status and conservation of Hazel Grouse in Europe. Ornis Scand 22:297-298

Vauhkonen J, Imponen J (2016) Unsupervised classification of airborne laser scanning data to locate potential wildlife habitats for forest management planning. Forestry 89(4):350-363

Wiesner J, Bergmann H-H, Klaus S (1977) Siedlungsdichte undHabitatstruktur des Haselhuhns (Bonasa bonasia) im Waldgebietvon Bialowieza (Polen). J Ornithol 118:1-20

Zellweger F, Braunisch V, Baltensweiler A, Bollmann K (2013) Remotely sensed forest structural complexity predicts multi species occurrence at the landscape scale. For Ecol Manag 307:303-312

Zhang J, Kissling WD, He F (2013) Local forest structure, climate and human disturbance determine regional distribution of boreal bird species richness in Alberta, Canada. J Biogeogr 40:1131-1142. https://doi.org/10.1111/jbi.12063

Publisher's Note Springer Nature remains neutral with regard to jurisdictional claims in published maps and institutional affiliations. 